\title{
JAK2 Exon 12 Mutation
}

National Cancer Institute

\section{Source}

National Cancer Institute. JAK2 Exon 12 Mutation. NCI Thesaurus. Code C158677.

A molecular genetic abnormality indicating the presence of a mutation in exon 12 of the JAK2 gene. 